\title{
STUDI AWAL BAHAN DASAR PIRANTI SOLAR CELL PADA PASIR SAMBERA MUARA BADAK MENGGUNAKAN XRF DAN XRD
}

\author{
Arief Muliawan \\ Sekolah Tinggi Teknologi Bontang \\ JIn. Ir. H. Juanda No.73 RT.36 Bontang, Kaltim \\ ariefstitek@gmail.com
}

\begin{abstract}
ABSTRAK
Penelitian tentang karakterisasi pada Pasir Sambera Muara Badak telah dilakukan. Penelitian ini bertujuan untuk studi awal bahan dasar piranti solar cell berupa Silika $\left(\mathrm{SiO}_{2}\right)$ yang bersumber dari alam. Sampel pasir kemudian dibersihkan dari kotoran kemudian dihaluskan dengan mengunakan ball milling. Setelah halus kemudian sampel dikarakterisasi menggunakan alat XRF dan XRD. Berdasarkan hasil XRF Pasir Sambera memiliki kandungan senyawa Si sebesar 79.1\% dan $\mathrm{Al}$ sebesar 14.9\%. Jika dibandingkan dengan hasil XRD Pasir Sambera jarak bidang difraksi pada intensitas tertinggi (100\%) yang dapat dilihat yakni pada sudut $2 \theta=26,7321$ dengan bidang difraksi 3,33 $\AA$ mengidentifikasi fase kuarsa.
\end{abstract}

Kata Kunci: Pasir Sambera, Silika, XRF dan XRD

\section{Pendahuluan}

Pemanfaatan energi terbarukan menggantikan energi fosil menjadi perhatian penting seluruh dunia. Pengunaan energi fosil untuk keperluan sehari-hari semakin meningkat seiring dengan perkembangan ilmu teknologi. Peran energi terbarukan harus dapat mereduksi energi fosil di masa yang akan datang. Salah satu energi terbarukan yang memiliki potensi yang cukup besar yakni energi surya dengan memanfaatkan radiasi. Energi radiasi dapat diubah menjadi arus listrik dengan menggunakan panel surya yang bahan bakunya terbuat dari bahan semikonduktor [1]. Bahan semikonduktor yang banyak digunakan dan mudah diperoleh saat ini ialah silikon. Namun silikon sangat jarang ditemukan dalam bentuk bebasnya, silikon dapat dijumpai dalam bentuk senyawa silika $\left(\mathrm{SiO}_{2}\right)$, sehingga untuk menghasilkan silikon yang murni, maka diperlukan kemurnian silika yang tinggi pula. Silika yang dimanfaatkan untuk bahan baku pembuatan panel surya harus mempunyai kemurnian sebesar 99,99\% [2].

Ketersediaan sumber alam berupa beberapa material di Sambera, Kalimantan Timur seperti silika, dapat diolah lebih lanjut sebagai nanomaterial dengan karakteristik yang khas. Nanomaterial ini dapat dibuat dalam ukuran nano $(<100$ $\mathrm{nm})$ melalui ball milling. Alat ini dapat mereduksi ukuran partikel dengan menggunakan bola-bola besi yang berputar pada suatu wadah untuk memberikan beban dinamis agar menjadi serbuk [3]. Penggunaan peralatan X-ray Diffractometer dan X-ray fluorescence akan menghasilkan karakteristik rinci nanosilika tersebut, menyangkut struktur dan unsur material. Penelitian pengujian menggunakan XRD telah dilakukan oleh penulis dalam menentukan hasil keluaran dari filter [4,5]

Tujuan dari penelitian ini adalah sebagai studi awal untuk mencari atau mengidentifikasi unsur atom/oksida yang terkandung di dalam pasir dengan kemurnian $(>50 \%)$ terutama pada pasir sambera. Bahan alam tersebut akan dibersihkan dan diproses dengan metode milling untuk proses serbuk (ukuran mikron) dan identifikasi kandungan oksida silika (pasir sambera) melalui uji X-Ray Flourescence dan X-Ray Difraction. Dengan demikian penelitian ini adalah sebagai studi awal dari riset lanjutan yaitu 
sintesis oksida silika $\left(\mathrm{SiO}_{2}\right)$ berbasis bahan alam dengan metode yang efisien.

\section{TINJAUAN PUSTAKA}

Pasir kuarsa adalah bahan galian yang terdiri atas kristal-kristal silika $\left(\mathrm{SiO}_{2}\right)$ dan mengandung senyawa pengotor yang terbawa selama proses pengendapan. Pasir kuarsa juga dikenal dengan nama pasir putih yang merupakan pelapukan batuan mineral utama seperti kuarsa dan feldspar. Hasil pelapukan kemudian tercuci dan terbawa oleh air atau angin yang terendapkan di danau, sungai dan laut. Dalam penelitian yang dilakukan oleh Totok Wianto dan Ninis Hadi Haryanti menjelaskan bahwa potensi material nano sangat besar dan perlu dikembangkan. Material nano hasil pengukuran yang berpotensi dikembangkan yakni pasor besi, kuarsa, kaolin yang mengandung clay dan zirkonium. Kadar pasir silika dengan kadar $\mathrm{SiO} 2$ sekitar 94,4\%-99\% [6]

Dalam penelitian lanjutan yang dilakukan oleh Totok Wianto, nurma sari darminto dan suminar pratapa dijelaskan bahwa pada daerah kalimantan terutama daerah banjarbaru ketersediaan silika sangat melimpah. Untuk mengolah silika lebih lanjut sebagai nanomaterial dengan karakteristik yang khas perlu dibuat dalam ukuran nano $(<100 \mathrm{~nm})$ melalui sintesis metode gaya berat kemudian melalui proses penggilingan menggunakan planetary ball milling. Penggunaan perlatan X-ray diffractometer (XRD) dan Scanning electron microscope (SEM) serta transmission election microscope (TEM) akan menghasilkan karakteristik rinci nano silika tersebut, menyangkut struktur, bentuk dan ukuran partikel serta agregasi yang mungkin terjadi [7]

Penentuan unsur material dengan pengujian XRF dan XRD telah banyak dilakukan. Penentuan unsur Fe, $\mathrm{Ca}, \mathrm{Ti}, \mathrm{Ba}$, $\mathrm{Ce}, \mathrm{Zr}$ dan $\mathrm{La}$ dalam sedimen laut telah dilakukan oleh Sukirno dan Sri Munrniasih pada tahun 2009. Penelitian yang dilakukan untuk mengetahui sebaran unsur-unsur yang mengakomodasi data lingkungan terkini dalam rangka mendukung ijin tapak dan analisis mengenai dampak lingkungan (AMDAL) pusat listrik tenaga nuklir (PLTN). Pengambilan cuplikan, preparasi maupun analisisnya mengacu pada prosedur analisis cuplikan lingkungan [8]. Penelitian serupa juga dilakukan oleh Nurul Fitri, Elin Yusibani dan Evi Yufita tentang indentifikasi kandungan material perekat pada benteng purba dikawasan aceh besar. Dari hasil pengujian terhadap material tersebut merupakan komposisi penyusun dari batu kapur jenis Kalsit. Jika dibandingkan dengan material perekat semen saat ini dengan komposisi yang berbeda. [9]

Tiga metode untuk memastikan bahwa kedudukan bidang tertentu dari hablur/ material yang dikaji memenuhi syarat-syarat Bragg pengukuran penyinaran difraksi. Ketiga metode ini adalah (1) metode difraksi laue; (2) metode hablur bergerak; dan (3) metode diftaktometeri serbuk [10].

Metode difraktometeri serbuk ialah untuk mencatat difraksi sampel polikristal. Pada analisis struktur material berbasis alam ini digunakan alat difraktometer yang pada prinsipnya seperti gambar 1 . Sampel serbuk dengan permukaan rata dan mempunya ketebalan yang cukup untuk menyerap alur sinar-X yang menuju ke atasnya. Puncak-puncak difraksi yang dihasilkan dengan menggunakan alat pencacah. Umumnya menggunanan alat Geiger dan sintilasi. Alat monitor dapat diputar mengelilingi sampel dan diatur pada sudut $2 \theta$ terhadap alur datang. Alat monitor dijajarkan supaya sumbunya senantiasa melalui dan bersudut tepat dengan sumbu putar sampel. Intensitas sinar-X yang difraksi sebagai fungsi sudut $2 \theta$ [11]. Difraksi sinar-x ini dapat menentukan lebar kisi kristal yang dibentuk dalam $n \lambda=2 d \sin \theta$ 


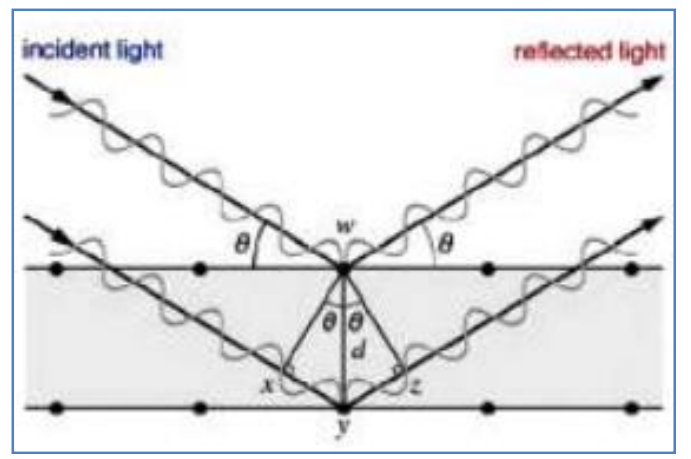

Gambar 1. Difraksi sinar-x pada bidang atom

Peralatan yang digunakan adalah XRD (merk Philips). Hasil difraksi sinar$\mathrm{x}$ dicetakkan pada kertas dengan sumber pancaran radiasi $\mathrm{Cu} \mathrm{Ka}$ dan dengan filter nikel. Data difraksi sinar-X dari pada sampel kemudian dibandingkan dengan kartu JCPDS (Joint Committee Powder Diffraction Standard). Dari nilai difraksi sinar-X yang menghasilkan intensitas dan sudut difraksi, dianalisis untuk menentukan jenis struktur kristalnya dengan mencocokan pada data ICSD (Inorganic Crystal Structure Database) untuk semua sampel yang diuji. Pada metode difraksi, hukum bargg haruslah dipenuhi, karena itu perlu diatur orientasi kristal terhadap berkas datang [12]. Metode sinar-X dapat dibedakan menjadi [11]: (1) Metode kristal tunggal. Metode ini sering digunakan untuk menentukan struktur kristal, dalam ini dipakai berbentuk kristal tunggal. (2) Metode serbuk (powder Method). Bahan sampel pada metode ini dibuat berbentuk serbuk,sehingga terdiri banyak kristal yang sangat kecil dan orientasi sampai tidak perlu diatur lagi kerena semua orientasi bidang telah ada dalam sampel dengan demikian hukum Bragg dapat dipenuhi. Metode lebih cepat dan lebih sederhana dibandingkan dengan metode kristal tunggal. Metode serbuk ini dapat digunakan untuk menganalisa bahan apa yang terkandung di dalam suatu sampel juga dapat ditentukan secara kwantitatif. Pada penelitian ini dipergunakan metode serbuk.
Informasi yang dapat diperoleh dari data difraksi sinar X ini yaitu: (1) Posisi puncak difraksi memberikan gambaran tentang parameter kisi (a), jarak antar bidang (dhkl), struktur kristal dan orientasi dari sel satuan; (2) intensitas relatif puncak difraksi memberikan gambaran tentang posisi atom dalam sel satuan; (3) bentuk puncak difraksi memberikan gambaran tentang ukuran kristalit dan ketidak-sempurnaan kisi.

Analisis menggunakan XRF dilakukan berdasarkan identifikasi dan pencacahan karakteristik sinar-X yang terjadi dari peristiwa efekfotolistrik. Efekfotolistrik terjadi karena electron dalam atom target (sampel) terkena berkas berenergi tinggi (radiasi gamma, sinar-X) dari pada energi ikat elektron dalam orbit $\mathrm{K}$, L, atau $\mathrm{M}$ atom target, maka elektron atom target akan keluar dari orbitnya. Dengan demikian atom target akan mengalami kekosongan elektron, dapat diisi oleh elektron dari orbital yang lebih luar diikuti pelepasan energi yang berupa sinar-X. Skematik proses identifikasi dengan XRF dapat dilihat pada Gambar 2 [13]

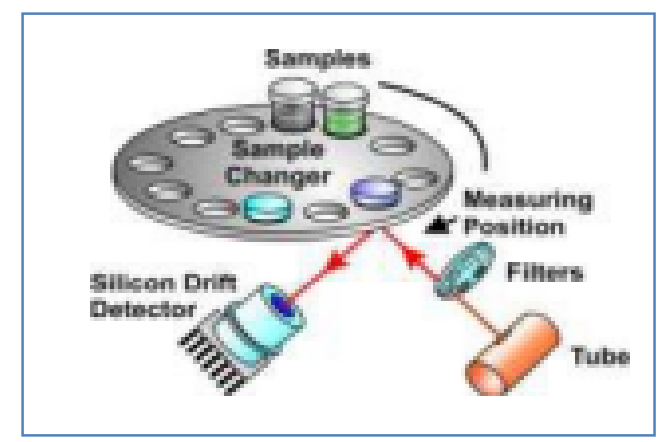

Gambar 2. Prinsip X-Ray Flourescence [13]

Sinar-X yang dihasilkan merupakan gabungan spektrum sinambung dan spektrum berenergi tertentu (discreet) yang berasal bahan sasaran yang tertumbuk elektron. Jenis spektrum diskrit yang terjadi tergantung pada perpindahan elektron yang terjadi dalam atom bahan. Spektrum ini dikenal dengan spektrum sinar-X karakteristik. Spektrometri XRF 
memanfaatkan sinar-X yang dipancarkan oleh bahan yang selanjutnya ditangkap detektor untuk dianalisis kandungan unsur dalam bahan. Bahan yang dianalisis dapat berupa padat massif, pelet, maupun serbuk. Analisis unsur dilakukan secara kualitatif maupun kuantitatif. Analisis kualitatif menganalisis jenis unsur yang terkandung dalam bahan dan analisis kuantitatif dilakukan untuk menentukan konsetrasi unsur dalam bahan. Sinar-X yang dihasilkan dari peristiwa seperti peristiwa tersebut diatas ditangkap oleh detektor semi konduktor silikon litium (SiLi) [13].

\section{METODE PENELITIAN}

Dalam penelitian ini diambil sampel dari bahan alam berupa pasir putih yang berasal dari desa sambera kecamatan muarabadak. Dari bahan ini kemudian dilakukan proses pemilihan dan penghalusan sehingga menjadi serbuk. Sampel yang telah disiapkan dari bahan alam kemudian dipilih dan diambil sebagian kecil diproses ke bentuk serbuk selanjutnya diayak (62 mesh-250 mikron), kemudian siap untuk dilakukan uji XRD dan XRF. Hasil uji difraksi sinar-X tersebut kemudian dianalisis kualitatif dengan metode search and match. Analisis kuantitatif XRD tersebut untuk menentukan struktur kristal dan komposisi unsur-unsur oksida yang terkandung dalam material alam tersebut. Untuk mendukung analisis tersebut dilakukan uji XRF.

\section{HASIL DAN PEMBAHASAN}

Hasil XRF diperoleh bahwa presentase senyawa $\mathrm{SiO} 2$ lebih tinggi dibanding senyawa yang lain. Hasil pengujian XRF pada sampel pasir desa sambera ditunjukan pada tabel 1:
Tabel 1. Hasil XRF Pasir Sambera

\begin{tabular}{|c|c|}
\hline Nama Senyawa & Persentase berat \% \\
\hline $\mathrm{Si}$ & 79.1 \\
\hline $\mathrm{Al}$ & 14.9 \\
\hline $\mathrm{K}$ & 2.16 \\
\hline $\mathrm{Ca}$ & 1.20 \\
\hline $\mathrm{Ti}$ & 1.18 \\
\hline $\mathrm{Fe}$ & 1.05 \\
\hline $\mathrm{Cr}$ & 0.15 \\
\hline $\mathrm{Cu}$ & 0.09 \\
\hline $\mathrm{Yb}$ & 0.08 \\
\hline $\mathrm{Ni}$ & 0.03 \\
\hline $\mathrm{V}$ & 0.05 \\
\hline $\mathrm{Mn}$ & 0.04 \\
\hline $\mathrm{Sc}$ & 0.01 \\
\hline
\end{tabular}

Dari tabel 1 dapat ditunjukan bahwa hasil pengujian XRF pada desa sambera menyatakan bahwa kandungan terbesar pada senyawa Si sebesar 79,1\% kemudian disusul oleh Al sebesar 14,9\%. Dengan kondisi kedua material tersebut dapat menunjukan bahwa Pasir Desa Sambera dapat dimanfaatkan sebagai sumber senyawa Si berupa silika dan Al berupa aluminium oksida. Dalam pemisahan dengan material lain diperlukan teknik pemisahan untuk mendapatkan senyawa Si dan Al yang murni.

Hasil XRD dilakukan dengan menggunakan tabung anoda $\mathrm{Cu}$ dengan panjang gelombang $1,54060 \AA$. Berikut ini adalah hasil uji XRD dalam tampilan program

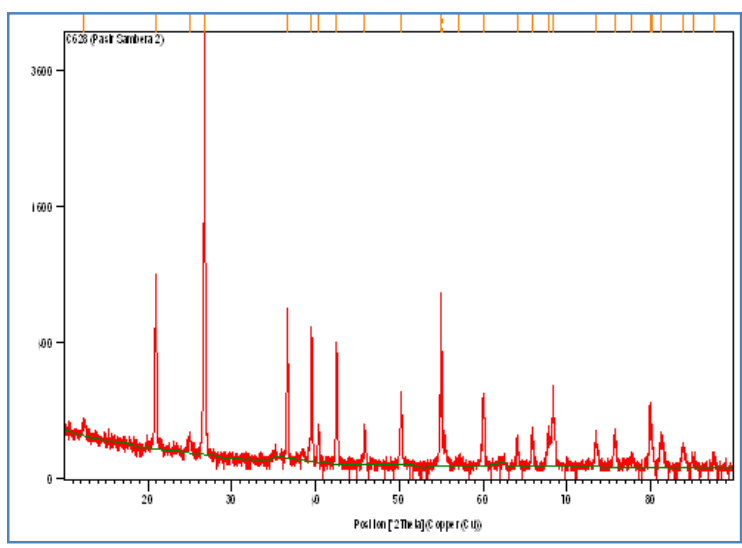

Gambar 3. Grafik hubungan intensitas dengan sudut difraksi

Pola difraksi XRD terdiri dari beberapa peak. Intensitas peak diplot dalam sumbu y dan sudut difraksi yang 
terukur diplot dalam sumbu x. setiap peak atau reflection dalam pola difraksi terjadi akibat sinar $\mathrm{X}$ yang terdifraksi dari bidang atau planes dalam specimen atau material yang diuji XRD. Setiap peak mempunyai tinggi intensitas yang berbeda. Intensitas yang terjadi berbanding lurus dengan jumlah foton sinar $\mathrm{X}$ yang telah terdeteksi oleh detektor untuk setiap sudut.

Posisi peak-peak yang terjadi pada uji XRD tergantung dari struktur kristalnya, hal ini yang dapat digunakan untuk menentukan struktur dan parameter kisi dari material yang diuji.

Hasil karakterisasi XRD pada sampel berupa intensitas difraksi sinar-X yang terdifraksi dan sudut-sudut yang terbentuk diatur berkisar antara $10^{\circ}$ sampai $89,9^{\circ}$ sehingga menyebabkan terjadinya variasu $d$-value ( $\mathrm{\AA})$. Hasil XRD dapat ditunjukan pada tabel berikut:

Tabel 2. Hasil XRD pasir Sambera

\begin{tabular}{|c|c|c|c|c|}
\hline \multicolumn{2}{|c|}{ Date $10 / 4 / 2017$ Time $11: 01: 21 \mathrm{AM}$} & \multicolumn{3}{|c|}{ File: C628 (Pasir Sambera 2) } \\
\hline Pos.[02Th.] & Height [etz] & PUHM[?2Th.] & $d-$ spacing $[\mathrm{k}]$ & Rel.Int. [?] \\
\hline 12.3863 & 28.68 & 0.2362 & 7.14619 & 0.66 \\
\hline 20.9343 & 882.97 & 0.0984 & 4.24357 & 20.37 \\
\hline 24.9505 & 22.63 & 0.2362 & 3.56805 & 0.52 \\
\hline 26.7321 & 4335.62 & 0.0787 & 3.33492 & 100.00 \\
\hline 36.6379 & 594.07 & 0.0590 & 2.45282 & 13.70 \\
\hline 39.5248 & 499.26 & 0.0590 & 2.28007 & 11.52 \\
\hline 40.3535 & 45.85 & 0.2362 & 2.23514 & 1.06 \\
\hline 42.5035 & 390.31 & 0.0787 & 2.12692 & 9.00 \\
\hline 45.8586 & 53.23 & 0.1968 & 1.97802 & 1.23 \\
\hline 50.1902 & 160.27 & 0.0787 & 1.81773 & 3.70 \\
\hline 54.9532 & 759.76 & 0.0720 & 1.66953 & 17.52 \\
\hline 55.0959 & 353.84 & 0.0720 & 1.66968 & 8.16 \\
\hline 57.1978 & 3.14 & 1.1520 & 1.60923 & 0.07 \\
\hline 60.0055 & 157.32 & 0.1440 & 1.54047 & 3.63 \\
\hline 64.1089 & 18.54 & 0.3840 & 1.45141 & 0.43 \\
\hline 65.8059 & 52.62 & 0.0960 & 1.41803 & 1.21 \\
\hline 67.7985 & 45.58 & 0.1440 & 1.38112 & 1.05 \\
\hline 68.3887 & 182.76 & 0.0960 & 1.37064 & 4.22 \\
\hline 73.4842 & 45.63 & 0.0960 & 1.28766 & 1.05 \\
\hline 75.6999 & 48.04 & 0.1680 & 1.25539 & 1.11 \\
\hline 72.7557 & 7.59 & 0.5760 & 1.22725 & 0.1 ? \\
\hline 79.9333 & 105.80 & 0.0720 & 1.19920 & 2.44 \\
\hline 80.1606 & 55.23 & 0.1440 & 1.19638 & 1.27 \\
\hline 81.1966 & 39.72 & 0.1440 & 1.18371 & 0.92 \\
\hline 83.8897 & 20.60 & 0.2880 & 1.15243 & 0.48 \\
\hline B5.1200 & 6.69 & 0.5760 & 1.13889 & 0.15 \\
\hline 87.5325 & 6.94 & 0.5760 & 1.11360 & 0.16 \\
\hline
\end{tabular}

Dari tabel 2 terlihat bahwa jarak bidang difraksi pada intensitas tertinggi $(100 \%)$ yang dapat dilihat yakni pada sudut $2 \theta=26,7321$ dengan bidang difraksi 3,33 . Hasil ini jika dibandingkan dengan penelitian Florke et al [14], bahwa fase kuarsa dapat ditunjukan pada bidang difraksi 3,34 $\AA$ dan 4,26 A. Selain itu menurut Munasir [15] posisi sudut yang menghasilkan intensitas maksimum dan teridentifikasi sebagai fase kuarsa ialah pada posisi $2 \theta=26,61^{0}$. Dengan demikian dapat dinyatakan bahwa sampel pasir Desa Sambera tersebut mengidentifikasi fase kuarsa.

\section{KESIMPULAN}

Berdasarkan hasil XRF Pasir Sambera memiliki kandungan senyawa $\mathrm{Si}$ sebesar $79.1 \%$ dan $\mathrm{Al}$ sebesar $14.9 \%$. Jika dibandingkan dengan hasil XRD Pasir Sambera jarak bidang difraksi pada intensitas tertinggi (100\%) yang dapat dilihat yakni pada sudut $2 \theta=26,7321$ dengan bidang difraksi $3,33 \AA$ mengidentifikasi fase kuarsa.

\section{DAFTAR PUSTAKA}

[1]. Halme, Janne. (2002). Dye-Sensitized Nanostructured and Organic Photovoltaic Cell: Technical Review and Preliminary Tests. Master of Science in Technology, Helsinki Universitas of Technology Finlandia.

[2]. Stanitski,L. (2003). Chemistry in Context. Edited by A.C. t. Society, 4th ed. New York: Mc Graw-Hill.

[3]. Xiao, Xu-xian, Ke-long Huang, and Qiong-Qiong He. (2007). Synthesis and characterization of aminated $\mathrm{SiO} 2 / \mathrm{CoFe} 2 \mathrm{O} 4$ nanoparticles. Transactions of Nonferrous Metals Society of China, 17(5), 1118-1122.

[4]. Muliawan, A. (2015). Studi Penurunan Kadar Logam Besi (Fe) Dan Logam Mangan (Mn) Pada Lempung Terhadap Perubahan Arus Listrik Dalam Solenoida. Journal Of Mathematics And Natural Sciences, 6(2), 1-8.

[5]. Muliawan, A. (2017). Metoda Pengurangan Zat Besi Dan Mangan Menggunakan Filter 
Bertingkat Dengan Penambahan Uv Sterilizer Skala Rumah Tangga. Jurnal Ilmiah Giga, 19(1), 8.

[6]. Totok Wianto dan Ninis Hadi Haryanti. (2008). Penentuan Mineral dan Logam Sebagai Material Dasar dalam Pengembangan Potensi Kalimantan Selatan sebagai daerah penghasil Nanomaterial. Jurnal Fisika Flux Vol.5 No.2

[7]. Totok Wianto, Nurma Sari, Darminto dan Suminar Pratapa. (2010) Sintesis dan Karakterisasi Nanosilika sebagai Upaya Pemanfaatan Potensi Sumberdaya Banjarbaru. Jurnal Fisika Flux. Vol.7 No.1

[8]. Sukirno, Sri Munrniasih. (2009). Analisa unsur $\mathrm{Fe}, \mathrm{Ca}, \mathrm{Ti}, \mathrm{Ba}$, $\mathrm{Ce}, \mathrm{Zr}$ dan La dalam sedimen Laut di Semenanjung Muria dengan metode XRF. Jurnal Iptek Nuklir Ganendra. Vol.1 No. 1

[9]. Nurul Fitri, elin Yusibani, Evi Yufita. (2016). Identifikasi kandungan Material Perekat Pada Benteng Purba di Kawasan Aceh Besar Menggunakan XRF. Journal of Aceh Physics Society. Vol. 5 No. 2 hal. 14-18

[10]. Munasir, Triwikantoro, M.ainuri, Darminto. (2012). Uji XRD dan XRF pada bahan mineral (Batuan dan Pasir) sebagai sumber material cerdas (CaCO3 dan $\mathrm{SiO} 2)$. Jurnal pendidikan Fisika dan aplikasinya. Vol.2 No.1

[11]. Cullity, B.D, 1956. Element of X-Ray Diffraction. Addison-Wesley Publishing Company, Inc.

[12]. Pratapa, S. (2010). Workshop Difraksi Sinar-X. Pusat
Penelitian Ilmu Bahan dan Ilmu-ilmu Dasar, LP ITS Surabaya, Indonesia.

[13]. Fansuri,H., 2010, Modul Pelatihan Operasional XRF. Laboratorium Energi dan Rekayasa, LPPMS ITS. Surabaya.

[14]. Florke, Ow, and H Schneider. (1986). Verwachsungsbesiehungen Der SiO2-Polymorphe Quarz, Cristobalit Und Tridymit In SiO2-Reichen Keramischen Werkstoffen. Paper read at CFI. Ceramic forum internasional, 63(7-8), 368372.

[15]. Munasir, Triwikantoro, Moch Zainuri, Darminto. (2013). Ekstaksi dan Sintesis Nanosilika Berbasis Pasir Bacar dengan Metode Basah. Jurnal Penelitian Fisika dan Aplikasinya (JPFA), 3(2), 1217 